\title{
On the Uses and Abuses of Nietzsche in Self-Help Literature
}

\author{
AnNe-GaËLle Argy
}

Friedrich Nietzsche is arguably one of the Western philosophers that authors and coaches of the self-help movement relate to the most. This paper hopes to clarify why that is the case, and to underpin the reasons why academia is so defiant when it comes to acknowledging the usefulness of Nietzsche's presence in self-help literature. ${ }^{1}$ Indeed, why are specialists (or long-time readers) of Nietzsche often confused when someone tells them that a self-help book about Nietzsche's ideas has changed their life, without this person ever having read Nietzsche's own writings?

It has become very clear that self-help literature is an enormous business (see Dolby). It strives to transform any kind of knowledge into ready-made advices and techniques, most of the time dearly sold as books, conferences, workshops, or even private counselling sessions. As the demand for such guides to every personal problem grows, many people from inside as well as outside academia worry about a strong and lasting tendency to betray subtle and complicated knowledge - whether artistic, philosophical, or psychological-by making it marketable. Then again, most professional philosophers agree that their field should not remain the restricted area of academic or trained philosophers, and most recognize that transmission is a key task for those who place philosophy at the core of their life and/or work, thereby stressing that public access to critical thinking is of primary importance. Indeed, shouldn't everyone be able to read and love philosophy, and to talk about it without having followed an academic training in the field? Why, then, do professional philosophers so often find it annoying to watch, hear, or even read self-help authors who often do seem to be doing their best to make abstract ideas accessible to a wider audience? Surely, a sentiment akin to jealousy is not the only issue in this persistent feeling that something is wrong in the way that authors of

\footnotetext{
${ }^{1}$ Throughout this paper I use the term "self-help literature" to mean an ensemble of discourses, practices, and techniques that strive to help personal flourishing, the development of personal creative capacities, and the soothing of personal sufferings. The term "inner flourishing" is sometimes favoured in the literature, though more as a spiritual expression.
} 
self-help books, coaches, "philotherapists," and/or philosophical counsellors use the works of philosophers to help people find their way in life - even if some of these coaches do earn a lot of money doing it.

Rather than a demonstration, this paper is an investigation into the self-help movement and its habits of appropriation. I will first draw a general sketch of the inspiration sources of self-help, of its psychological background, and of the specificities of its interest for philosophy: what does self-help promise, and how does it use philosophers to try to keep that promise? I will then focus on Nietzsche as a prominent example of the way that self-help adapts a philosophy to its own goals. Nietzsche is indeed one of the favourite philosophers of the self-help literature and movement. The books and websites consulted for this investigation are mainly from France and from the U.S., and they focus either specifically on Nietzsche or on philosophy more generally.

\section{The promise}

Let us start by thinking about self-help literature's use of philosophy with the most possible benevolence. In this view, one can judge it as a modern expression of the desire for reconciliation between what Michel Malherbe calls "Living Philosophy" (philosophie vivante), which is required, and "Academic Philosophy" (philosophie savante), which is instituted (Malherbe 65). ${ }^{2}$ This preoccupation spans the entirety of Western philosophy's history. ${ }^{3}$ We know of many attempts made throughout the centuries to communicate to a non-professional audience the results of a more speculative and abstract philosophy - attempts mainly led by a will of moral edification but also for the sake of science. This desire can also simply be an attempt to question the ways in which different kinds of human knowledge relate to one another. To name but a few, one can state Hume and the difference between "easy and obvious philosophy" and "accurate and abstract philosophy" (Hume I, 3); Locke and the difference between a "civil" and a "philosophical" use of words (Locke III, ix, 3); or even Deleuze's pop philosophie. Traditionally, the duty to operate this reconciliation is the philosopher's or the community of philosophers' task, as they are supposed to be keepers of the higher version of knowledge. Another way to operate this reconciliation has been to seek a common lexicon to all knowledge, albeit not conceived as a descent of the abstract

\footnotetext{
${ }^{2}$ All translations from works that are not published in English are mine.

${ }^{3}$ I focus here on Western philosophy because it is the tradition where the question of dualism between theory and practice arose. This opposition is at the heart of the interest of self-help literature for philosophy. All other traditions (for instance, the different strands of Buddhism, Hinduism, Taoism, etc.) are used precisely because they are supposedly more practical, and so immediately "ready" to be framed in self-help's interpretation of the task of philosophy, as we will see below.
} 
knowledge to the people (as traditionally offered, in a top-to-bottom transmission of knowledge) but rather, as the Encyclopédistes regarded it, such as to "make a tongue common to scholars and layman" (Le Ru 60). This common tongue was to be "simple and rational, compounded of scientific or technical terms, but duly defined by the vulgar terms or their derivatives" (60). The idea, here, is to offer a back-and-forth movement from the common language to the philosophical one, the aim being to enrich the common language without it becoming unintelligible, i.e. too technical for those without training.

There are thus two approaches: one that offers (almost religiously) a descent of a higher and abstract knowledge from the community of philosophers to a wider, non-specialist audience; and another that intends to enrich the natural knowledge of the public sphere via a back-and-forth movement that starts with the practical wisdom of the non-specialist audience, which specialists later improve and refine.

Self-help does not openly choose one of these approaches, and it usually seems to lack any interest in the distinction. Rather, it mixes them: it offers a translation of a technical knowledge (unintelligible to ordinary mortals) by "experts" who are able to undertake it, while at the same time being very critical of an academic philosophy that is purportedly obscure and abstruse because it has lost its only true mission, that of improving the fate of human beings by making suffering stop. (In this literature, suffering is generally understood as the direct report made by individuals who say they suffer, i.e. as a personal feeling immediately identifiable and describable.) It appears that the "experts" of the self-help movement, in most cases, want to distinguish themselves at the same time from the professional philosophers (deemed too abstract) and from the public (judged unable to understand the texts independently of an expert approach to them). This gap is the site of a privileged position regarding the two groups that are to be reconciled. Dug out by the experts, this gap is, of course, the very locus of the lucrative self-help business.

In the first chapter of his 1999 bestseller Plato, not Prozac, Lou Marinoff, an American philotherapist and counsellor, explains how he understands the role of philotherapists (who work in the psychoanalystinspired context of a private cabinet) and philosophical counsellors (comprised of business coaches and leaders of group discussions): "My fellow practitioners and I are not philosophers in the academic sense alone. Although many of us have PhDs, teach in universities, and publish specialized articles, we do more than that: we also offer client counselling, group facilitation, and organizational counselling. We take philosophy out of purely theoretical or hypothetical contexts and apply it to everyday personal, social, and professional problems." (Marinoff, Plato 6; my emphasis) These counsellors sell themselves as being more than philosophers, more than teachers, more than artists: they apply 
philosophy, ${ }^{4}$ and they market their ability in a way that leads readers to think that they are the firsts to do so. Now on what grounds do their claims rest? Is there a conceptual background that allows the authors of philosophical self-help to create their own space and business?

\section{The psychological background of philotherapy and philosophical counselling}

In 1942, Susanne Langer offered an explanation of the hidden movements of thinking which, like successive waves, cover and impregnate a culture. (She preferred the metaphor of "seasons.") She wrote that her time was the season-era of the symbol. Out of the soil of the era of "personal experience"- the leading concept of Western thinking, which "inspired philosophy from Descartes to the end of German idealism" (Langer 18) grew the era of the symbol, and it immediately split into two directions: modern logic (symbolic logic, theory of knowledge) and modern psychology (psychoanalysis). Langer's interpretation is fruitful inasmuch as it underlines a theme common to both directions: "the human response, as a constructive, not a passive thing" (24). Putting constructive human response at the centre of modern Western culture is one way to understand how self-help allowed itself to rise on the ground of psychology, and claimed to be its substance. ${ }^{5}$ The human person, understood as an individual, private self with central and unique feelings and emotions, is the core of the self-help field. Indeed, today individuals are generally considered as the only starting point from which we can legitimately look at and try to understand the world. Everything stems from the individual, from its ability to fit the world and its difficulties: its personal discomfort is what moves the individual, and it is the prism through which it interprets everything which happens in its sphere.

In this sense, one should not be surprised by the birth and success of philotherapy in the West. Indeed, it might be considered as a result of the melting pot that includes a focus on the individual, symbolic psychoanalysis, and the marketization of knowledge (in the sense that anything can be sold if properly marketed), in an outstandingly therapeutic time. Some authors summarize the first two elements in the idea of a "therapeutic culture," in which the "duties towards oneself" are the only

\footnotetext{
${ }^{4}$ Marinoff is also President of the American Philosophical Practitioners Association (APPA).

${ }^{5}$ Another of Marinoff's books is Therapy for the Sane: How Philosophy Can Change Your Life. He often insists on how philotherapy is the acme of therapy; other therapies should be restricted to really sick people. Doing so, he draws a clear limit between the realms of sane and insane people, and this obviously raises other difficulties. (See note 7 below.)
} 
true duties (see Illouz, Lasch, or Ehrenberg). ${ }^{6}$ The fulfilment of one's potential is a sine qua non condition not only for personal well-being or happiness, but also for integration into the social environment, i.e. for giving a coherent account of oneself, for blooming, for being able to manage one's emotions, being spontaneous, authentic, collaborative, selfish (but not too selfish), as these are personal but also social requirements. Adaptability seems to be the preliminary condition for any critical thinking: it applies to external problems only once one feels good and happy, perfectly adapted to one's social environment, leading a satisfactory, standardised life... in other words, such that the problems of the world are not a burden to one. If we add the desire to make money, everything is ready for a self-help business to arise. In this context, theories, practices, arts, and social movements are broadly classified and evaluated according to their therapeutic utility, i.e. their ability to ease suffering, increase well-being, help one adapt to the workplace and to the traditional private sphere (family, heterosexual couple...) - and all of this in the shortest time possible (indeed, this is a crucial selection criterion). Other aspects of life, such as political and social commitments, or even genuine curiosity about how things work, are said to be possible only when the internal personal equilibrium is reached (or re-established). Personal happiness and balance first - the rest will follow (or more probably, the rest will be forgotten on the way).

In this commercial therapeutic context, philosophy bears a specificity compared to other speculative disciplines. Indeed, it supposedly allows a more "objective" way to approach problems. ${ }^{7}$ Often compared to psychology, philosophy supposedly enables a perspectival view of things and an understanding of oneself in a wider frame-while psychology rather proposes to dig into one's intimacy in order to reach an individual and unique truth. One here recognizes the realm of reason as opposed to the realm of emotions. For instance, a French website, in an article on philotherapy, offers a summary on how the two disciplines confront the same problems in the context of individual consultations (see Horvilleur). While one tries to discover oneself in the office of a psychotherapist, in a consultation with a philotherapist one rather tries to understand oneself with more objectivity. During a philotherapy one learns to be sceptical rather than to stop doubting about oneself with a psychotherapist. One

\footnotetext{
${ }^{6}$ A great deal has been said, and there is still a lot to say, about the rise of self-help, i.e. where it comes from and what it says about us. For a rich and recent account of the notion of therapeutic culture from a sociological angle, see Marquis and Imber.

${ }^{7}$ This aspect is related to the idea of a "therapy for the sane," developed by Marinoff: the "sane" are able to a more "objective" approach of their problems than the "sick" who are unable to take such a distance from their difficulties.
} 
aims to master one's emotions instead of healing them. ${ }^{8}$ Gaëlle Jeanmart, a Belgian philosophy professor and philosophical counsellor, states that a philotherapeutic consultation offers "practice made of questioning, aimed at appeasing psychic and spiritual suffering that is related to the opinions, judgements, or representations about our life and about the difficulties we are confronted to." (Jeanmart 58)

We thus see that psychology, psychotherapies, psychiatry, and psychoanalysis (and not philosophy) are the first opponents of self-help, as they are supposed to offer the same service. Philosophy is not considered to be dangerous (perhaps because it has never been a lucrative business?). Marinoff insists on distinguishing the field of philotherapy as an answer to specific problems:

Many people who seek out philosophical counsellors have already been in therapy but found it ultimately unsatisfying, at least in some regard. People can be harmed by psychological or psychiatric treatment if their root problem is philosophical and the therapist or doctor they seek out doesn't understand that. A feeling of desperation can arise if you begin to feel that no one will be able to help you with your problem because you are not being listened to or heard clearly. Inappropriate therapy is a therapy that wastes time (at best), and can make your problem worse. (Marinoff, Plato 10)

Philotherapists offer to solve those specific problems, and in doing so they create a new need.

\section{The lie}

But let us get to the point: the promise of expertise, sold as an intermediary stage needed to ensure a real transmission of knowledge, is a lie. ${ }^{9}$ Indeed, in spite of the program of a large number of self-help books and websites, we are not witnessing an attempt to reconcile theoretical knowledge and popular wisdom (which is often said to be more "intuitive," "empirical," and even "realistic" than philosophical knowledge). We are not witnessing a high quality popularization, but rather a process of one-way borrowing from philosophy as a technical discipline, in order to feed a practice that, in its first phase, embraced the codes and vocabulary of modern psychology, and, in its second phase, rejected this source in order to select another field of knowledge that could

\footnotetext{
${ }^{8}$ Following his colleague Ran Lahay, Marinoff (Plato 17) uses the metaphor of the chess game to differentiate the psychologic, psychoanalytic, psychiatric, and philosophical approaches. The exposure and results of the metaphor are obviously caricatures.

9 This does not mean that the "therapy" has no effect on the patient. Many people seem to genuinely appreciate self-help books and their effects on their life (see Marquis).
} 
donate material to its business. In so doing, self-help steals from all arts, traditional knowledge, wisdom, and techniques. If a concept or theoretical ensemble seems too complex, it will be said to require too much explanation; if it is not quickly "efficient," it will be discarded or modified until it fits the only important criteria, that of rapid practical efficiency in order to soothe suffering and make the individual feel she or he fits the world.

But despite the prestigious aura of philosophy, books relying on philosophy are of the opinion that most philosophers have lost sight of their real task - that is, helping people to live better lives and to be happy. Even therapeutically inclined moral philosophers are said to have lost their way into abstractions that are at best useless, and at worst malicious (since they serve to isolate the average folk from the small community of scholars). Therefore professional "experts" often criticize philosophers and accuse them of maintaining a position of power. Tim Ferriss, a wellknown American self-help entrepreneur and bestselling writer (see, e.g., Ferriss 4-Hours), gives such an example: "Most of us can recall at least one turtleneck-wearing intellectual in college who dedicated countless hours of study to the most obscure philosophical points of Marx or poststructural lesbian feminism. For what? Too often, to posture as a superior intellect at meal time or over drinks." (Ferriss "Stoicism") ${ }^{10}$ Luckily, Ferriss further writes that "Fortunately, there are a few philosophical systems designed to produce dramatic real-world effects without the nonsense." Here Ferriss alludes mainly to Stoicism, as also does Ryan Holiday, author of the 2014 bestseller The Obstacle is the Way. ${ }^{11}$ And indeed, who are self-help's main philosophers and currents?

\section{The "hit parade of philosophers" 12 and Nietzsche}

The unchallenged philosophical stars of self-help are ancient Greeks (mainly Aristotle and Plato) and Roman Stoics. Asian philosophies are also well represented (especially Buddhism and Taoism). After these, the most used authors are Kant (mainly for the categorical imperative), Thoreau and Transcendentalism (mostly in the American self-help literature), and, finally, Nietzsche, who occupies quite a good position in European and in American literature. (Other philosophers are sometimes mentioned or used for specific purposes, as will be mentioned below.)

\footnotetext{
${ }^{10}$ Tim Ferriss is also an advocate of the "practical philosophy" movement. For a good example of his approach, see Ferriss "Philosophy as a Personal Operating System."

${ }^{11}$ Holiday's 2014 book is now published in 17 languages. Its back cover reads: "The book draws its inspiration from stoicism, the ancient Greek philosophy of enduring pain or adversity with perseverance and resilience."

${ }^{12}$ Marinoff, Plato 284.
} 
Nietzsche is indeed interesting to focus on as some of his work tackles notions that the reader can relate too at an individual level: he is a reference one can rely upon to justify one's own choices. As a consequence, I will focus on two aspects of Nietzsche's work that (if only partly) help explain the interest of self-help for his work: his aphoristic writing (since synthetizing thoughts in shock-phrases is a sine qua non of self-help authors), and the status and legitimization of suffering.

\section{The appeal to the authority of tradition}

The figure of the philosopher first allows self-help to call on the authority of a tradition of thought that is used to legitimate certain personal principles and feelings. Some books give examples of how everyday problems are solved or simplified by calling out to a philosopher or a school of thought for help (see Marinoff, Plato 132). ${ }^{13}$ It seems that in the realm of self-help most famous philosophers have a specific role to play in the way that they are used to legitimate a state of affairs or to slightly change a point of view on a situation. (They are rarely used, though, to incite radical changes in one's life.) In Nietzsche Anti-Stress, Allan Percy draws up a list of the "specialties" of the best-known philosophers, the criteria for this classification being the kind of problem the philosophers help solving. For instance, according to Percy, we should read Buddha to find love, but also Lao Tzu, Aristotle, and Seneca; to face the fear of death, Beauvoir, Lao Tzu, Hume, and Confucius are recommended; if you are dissatisfied, Voltaire, Rousseau, Aristotle, and the Bhagavad Gita are of help; and so on (Percy 217). In the way they are used, philosophers become figures more than thinkers; their works are pared down so that people might easily remember them as answers to specific problems.

In this context, calling to Nietzsche, whether to his work or personality, ${ }^{14}$ firstly means to draw benefits from his aura as immoralist. It is not clear what meaning of this term self-help books advocate, ${ }^{15}$ but we

\footnotetext{
${ }^{13}$ Marinoff gives the example of a woman named Margaret who was troubled by a discussion she had with a friend regarding whether to give pocket money to her children in exchange for some "work" or for "free." Margaret purportedly found confirmation of her opinion through Aristotle and Confucius. Furthermore, it seems that she was relieved by the idea of sharing common "problematics" with famous philosophers. Here, the thought "If they say so too, it must be that I am right" seems to be the underlying idea: to find one's opinion in someone else's more legitimate thinking can be empowering.

${ }^{14}$ It is unlikely that authors will detach Nietzsche-the-philosopher from Nietzsche-theman, which is not the case with other philosopher used in self-help. The back-cover of Armstrong's Life Lessons from Nietzsche gives an example of this.

15 For instance, Marinoff writes that Nietzsche "advocates the emergence of the Übermensch (superman) who would transcend conventional morality" (Marinoff, Plato 284).
} 
can tentatively see that the example of his life as a free thinker helps one to think out of the box, i.e. out of traditional frames. Nietzsche helps us to be "politically incorrect," and he thus serves as the philosophical authority that helps one to be free from authority. In the "hit parade of philosophers," as Marinoff puts it, Nietzsche is the philosopher whose theme (musically speaking) is "the extravagant anti-conventionality" (Marinoff, Plato 284). He is also frequently quoted when contradiction is at stake. (Indeed, contradiction is a serious issue for self-help, as self-help is inherently contradictory! ${ }^{16}$ Contradiction must then either be valued or denied as a problem: I will return to this issue below.)

Part of Nietzsche's position in the pantheon of chosen philosophers is due to the opinion that his thought could be approached without too much intellectual effort. That, for instance, is the task that the editor of Life Lessons from Nietzsche undertakes, as one can read from the book's back cover:

You may ignore it, but Nietzsche's thinking is immediately and easily applicable to our everyday lives. The author [John Armstrong], inspired by the work just as much as by the life of the German thinker, extracted the very substance of his wisdom, and invites us to use it to live better. Enriched with many quotes, understandable by everybody, this book will for sure be a valued companion on the road to happiness. ${ }^{17}$

More briefly put: Nietzsche is an easy philosopher, although nobody knew it before Armstrong's book. The book's program is not fulfilled, though, since it consists of many quotes from Nietzsche's work-some very long (quotes range between a few lines and four pages!) - that are chosen to illustrate the theme of each chapter, such as: How to Find your Real Self, On Changing one's Mind, Don't pull your Punches, and so on. Hardly any explanation is given, and when there is, it only serves to articulate the quotes...

\footnotetext{
${ }^{16}$ As Eva Illouz explains, within the realm of self-help one has to "become self-reliant, yet attuned to others' needs; conduct relationships in a highly rational way, yet be focused on its own and others' emotions; be a unique individual, yet constantly cooperate with others." (Illouz 243)

${ }^{17}$ Whether the editor wrote this text with the author or not is unspecified. Armstrong's book is part of Macmillan's "The School of Life" series, which refers to Alain de Botton, a well-known name in the self-help domain and founder of the School of Life. Macmillan also published "Life Lessons" from Bergson, Kierkegaard, Hobbes, Byron, and Freud. On its website, the publisher prestigiously describes Armstrong as a "Philosopher in Residence at the Melbourne Business School and Senior Advisor to the Vice-Chancellor of Melbourne University." (https://www.panmacmillan.com/authors/john-armstrong, consulted Nov. 8, 2016)
} 
Notwithstanding, it would be dishonest to focus solely on the most problematic self-help books, since some authors do appear to be honest in their desire to help a wide audience enjoy the benefits of philosophy and develop autonomous thinking. An example of this is found in the French book series "Vivre en philosophie" ("To live philosophically"). Each volume is dedicated to a philosopher and written by authors who seem to possess a genuine experience in knowledge transmission. It is legitimate to think that this series (also better than many others as regards the content's rigor) would permit a non-professional audience to grasp a synthesis of each philosopher's work, or at least some aspect of it, or to incite readers to turn to the philosophical texts themselves. But once again, the titles reveal the underlying goal of the series: not knowing, but rather operating modifications within oneself. This is immediately made clear by the action verb that is the mark of each title: Act with Aristotle (and not, say, Action in Aristotle's Philosophy), Being Happy with Spinoza (and not Happiness...), Letting go with Schopenhauer, Living Passionately with Kierkegaard, Enjoying the Present with the Epicureans, Growing up with Pascal, Being Yourself with Heidegger, Valuing Oneself with Descartes, Being Free with Sartre, and, of course, Balthasar Thomass' Asserting Yourself with Nietzsche. ${ }^{18}$

The promise that emerges from these books is basically one of transforming one's life via exercises inspired by the work of the selected author. The books in this series all have the same introduction, namely a mode d'emploi ("User's Manual"), ${ }^{19}$ and are divided into four parts: (1) Symptoms and Diagnosis, (2) Keys of Understanding, (3) Means of Action, and (4) A Vision of the Meaning of Life. Then, each chapter closes on a set of "philo-actions" that offer practical answers to the subject matter developed in the chapter. For instance, in the volume on Nietzsche, at the end of the chapter "Slowing down to become strong," one reads: "Each time you face a difficulty, or meet an opposition, or are saddened, ask yourself in which way this difficulty can help you progress, how it can make you stronger, how the manure of life can become its fertilizer." (Thomass 127) ${ }^{20}$ At the end of the chapter "Loving your enemies," one reads: "If you are full of hatred, always try to find out how your enemy can enrich and reinforce you, and try to feel gratitude." (169) ${ }^{21}$ The first

\footnotetext{
${ }^{18}$ All original French titles and references are given in the Works Cited list below.

${ }^{19}$ As the introduction states, the book is "not only a book to read, but a book to perform" ("Pas seulement un livre à lire, mais aussi un livre à faire") (Thomass XIII).

20 "Chaque fois que vous rencontrez une difficulté, une résistance, un chagrin, demandezvous en quoi cette difficulté peut vous faire avancer, vous rendre plus fort, en quoi le fumier de la vie peut en être aussi le fertilisant."

21 "Si l'hostilité vous remplit de haine, pensez toujours en quoi votre ennemi peut vous enrichir et vous renforcer et essayez de ressentir de la gratitude."
} 
chapter of the book, dedicated to symptoms and diagnosis, is focused on nihilism and the virtues of illness. After some rather consistent developments on nihilism in Nietzsche's work, the chapter ends with a boxed text, "Vital Questions," that proposes exercises: "Next time you fall ill or you feel pain, even temporary, pay attention to the way pain modifies your perception. Do you feel more distant or closer to things? Do they seem brighter, or more neutral? Could you keep something of this perception influenced by pain and use it in your 'normal' life?" (9)

The text thus translates into a very simplified exercise on a whole life (Nietzsche's) spent questioning the relationship between pain and interpretation. This simplification does not allow the reader to think about the value of pain. It rather guides the reader to the answer: pain has to be helpful, and it can be used in some way. In other words, pain has to have a meaning and a dedicated space in our personal histories! The problem, then, is not the accuracy of what is said on one philosopher or another, nor the legitimacy of the writer of the book, but rather what the author does with his or her knowledge about the philosopher. Offering philosophical or spiritual "exercises" is definitely not a novelty (e.g., see Hadot). What is new is to offer exercises as very specific behavioural advices taken from any philosophy, without any thought give to the author's ideas or opinions on the subject. What is betrayed here is not philosophy understood as a high-valued discipline, or Nietzsche as a "great philosopher," but rather the tremendous efforts made by thinkers throughout the centuries to explain the world or to make it more bearable. The self-help frame is always the same, and it seems that any thought can be distorted enough to fit into it so as to offer a ready-made practice aimed at making life easier and humans happier. But such a super-simplification might render the practice counter-productive.

\section{The art of shock-phrases and aphorisms}

One of the crucial aspects of the interest of self-help authors for Nietzsche is related to his art of aphorism. In her book dedicated to the success of self-help literature in the U.S., Sandra Dolby dedicates a chapter to the use of proverbs and quotes. She shows that self-help authors very often try to summarize their message in order for readers to easily remember sentences. Shock-phrases are even used as book titles (Dolby 143), as is the case with Wherever You Go, There You Are (Kabat-Zinn), Do What You Love, the Money Will Follow (Sinetar), or End the Struggle and Dance With Life (Jeffers). Shock sentences are mixed throughout the texts with quotes from Nietzsche, Epicurus, or Buddha. The new sentence, forged by the self-help author, is thereby reinforced by the proximity of the original aphorism and its textual authority. Self-help authors can then introduce their (or their colleagues') homemade phrases, thereby fitting 
into a more prestigious corpus. As Dolby writes, this procedure is a common technique looking to add prestige and authority to a new work: "The proverb-like wisdom and wide applicability of such sayings are what make them so effective in self-help books. They are a significant part of the traditional pool of resources that come together in modern self-help books and grant them an air of both ancient wisdom and modern creativity." $(146)^{22}$

As regards Nietzsche, the most quoted of his aphorisms, used as undisputable pieces of wisdom from the past (and selected, here, from various self-help websites, books, magazines, and Instagram and Twitter self-help accounts), are: "What does not kill me makes me stronger" (Twilight, Maxims §8), "One must still have chaos in oneself to be able to give birth to a dancing star" (Zarathustra, Prologue §5), "Without music life would be a mistake" (Twilight, Maxims §33), "What is done out of love always takes place beyond good and evil" (Good and Evil §153), "The higher we soar the smaller we appear to those who cannot fly" (Dawn §574), and even "I would only believe in a god who could dance" (Zarathustra I, On reading). These quotes all have something is common: they are immediately applicable to oneself as an individual (and not as a political subject or as a member of a community). They can easily be used to justify one's choices and personal emotions, and to enhance the feeling of being different from others. Confusedly, one can recognize oneself in them, and derive some power from the idea of what we already are as individuals subjected to emotions, and nothing more. When so extracted from their context, these sentences say nothing about the world, but only about the reader and her/his intimate relation to the world, to whom they "speak" so directly. It does not seem to matter if we can relate to several striking sentences that contradict one another, as long as they first appeal to our emotions and personal history. ${ }^{23}$ These sentences, indeed, are sidelines of a practice, and as such they are not supposed to be judged as ideas to be discussed ${ }^{24}$ or as arguments of debate. One must just feel them.

22 The power of aphorisms, new and old, explains partly why Hindu and Buddhist philosophies are easily put to practice, as they are issued from traditions where texts are often offered in the form of very dense formulas, or stanzas, to think, meditate, and comment upon.

${ }^{23}$ A French book is remarkable in this sense: Jean-Yves Clément's Nietzsche au jour le jour: un florilège pour tous et pour personne (Nietzsche Day in Day Out: A Collection for Everyone and No One) is a selection of 365 quotes (there is no Feb. 29 ${ }^{\text {th }}$ ) from Nietzsche's works (his published books and his Nachlass, with no references given), that make up, as he openly admits in the introduction, his Nietzsche. Indeed, the only link between the chosen quotes is the man who selected them to say things about... himself, although Clément's name does not even appear on the book's cover!

${ }^{24}$ It is easy to notice that on social networks (Twitter, Facebook, or Instagram), the comments posted to quotes or aphorisms more often take the form of "That's me!!" than of "That's true!!" Whether this is a strong tendency would need further investigation. But 
The tendency to isolate short sentences from their context to make them serve a personal goal is not specific to self-help. (Perhaps academic literature of every walk of knowledge should be more careful about this habit.) But Nietzsche presented his aphorisms to his readers in a specific order that serves a purpose. Aphorisms appear in a certain context that should be at the very least mentioned, if not respected, if someone is to understand Nietzsche's ideas. Nietzsche himself was aware of the risks posed by aphorisms: in the 1887 foreword to the Genealogy of Morals, after a warning concerning the difficulty of his three essays, he writes: "An aphorism properly coined and cast into its final mould is far from being 'deciphered' [enteziffert] as soon as it has been read; on the contrary, it is then that it first requires to be expounded - of course for that purpose an art of exposition [Kunst der Auslegung] is necessary." (§8)

Even if we stay alert to this and try not to make Nietzsche himself a critic of self-help, it is impossible not to notice how the use of aphorisms by self-help literature is at odds with what he encouraged as a practice of reading. As Alexander Nehamas summarizes it, "Aphorisms, of course, are not systematic, not discursive, not argumentative; also, for the most part they are much more difficult to interpret than they at first appear." (Nehamas 14) Their fragmentary nature is precisely supposed to make them difficult to understand, and their style aims in part to protect ideas from the temptation to fit them into a rigid system. As Walter Kaufmann, argues this difficulty is related to the fact that Nietzsche is, "like Plato, not a system-builder, but a problem-thinker". (Kaufmann 82, quoted in Nehamas 15) Self-help does exactly the opposite with Nietzsche's work, and more specifically with his aphorisms, offering a simplistic, final interpretation of them. As Sarah Kofman put it, the aphorism, "because of its discontinuous character, disseminates meaning; it is an appeal to a pluralism of interpretations and to their renewal: nothing is immortal except movement." (Kofman 168, quoted in Nehamas 16) Thus, by focusing on the form given to a thought, one can say that by applying Nietzsche's aphorisms, self-help does exactly what the aphoristic form is supposed to protect against.

\section{Suffering: "What does not kill me makes me stronger"}

To insist on what I have just stipulated about misinterpretation it is relevant to focus on the status of suffering in self-help literature. It is important to stress that suffering is the obsession and Nemesis of self-help (see de Botton). But at the same time it is soon valued as the most apparent symptom of unsuitability to one's environment, and as the

it suggests that our will and ability to evaluate a statement rests more (and more?) upon a possibility to relate to the statements, and not so much to evaluate its accuracy. 
occasion to learn something as well. Now, since Nietzsche does not condemn suffering straightforwardly but rather deeply questions its value, he thereby provides elements to self-help literature that give a meaning to suffering. ${ }^{25}$ Although Nietzsche's view on suffering is complex,${ }^{26}$ he could seem close to the basic idea sold by self-help, namely that suffering is a symptom of an inadequacy between our lives and our desires. Self-help, though, proposes to ease suffering, or to interpret it as something deserved - alongside Christian thought - or transitory on the road towards a happier state of existence. In so doing, self-help interprets a weakness as a virtue. Nietzsche, on the contrary, questions the roots of these attributed values. The way we react to suffering, and the value we attribute to it, is related to states of health and of décadence, to our position between them. This issue of a culture of décadence, so important to Nietzsche's thought, ${ }^{27}$ is never addressed by self-help literature, focused as it is on immediate individual well-being as the source of every possible change.

To emphasize the contrast between this analysis and the goal of self-help, let us look at some of the 99 short chapters of Allan Percy's Nietzsche Antistress. They are called "philosophical pills," and consist of quotes that are extracted from their context to fuel one or two subsequent paragraphs aimed at helping one to accept, and to give meaning to, difficulties (or to see them as opportunities). Pill 84 is arguably Nietzsche's most famous quote: "What does not kill me makes me stronger."28 (Twilight I, §8) To illustrate it, Percy names as an authority the French psychologist Boris Cyrulnik, who bases his work on the concept of resilience, i.e. the ability to overcome a trauma in order to go back to one's personal life. Percy ends his illustration by summarizing: "If torment does not kill us, as Nietzsche underlines, it helps us acquire an essential vital experience to help us face future difficulties and to save our

${ }^{25}$ In de Botton's Consolations de la philosophie, the chapter dedicated to Nietzsche is related to the task of "facing difficulties." De Botton believes that Socrates is the philosopher we might rely on to face issues related to unpopularity; Seneca, in cases of frustration; and Schopenhauer, if we are heartbroken.

${ }^{26}$ On the status of suffering in Nietzsche's philosophy and its relation to the issue of the will to power, see Wotling (more specifically Part II, Ch. 2: "Le problème fondamental: la réaction face à la souffrance," 137-154; and 140 on the dualism between pain and pleasure as a symptom of décadence).

27 "Building a culture on values that express a fear and refusal of suffering is a dangerous undertaking, since weakness is characterized by its ingenuity to invent remedies that immediately ease, but that in the long run produce a worsening of, the décadence" (Wotling 153).

28 "Aus der Kriegsschule des Lebens. - Was mich nicht umbringt, macht mich stärker." This idea of the sentence being part of an aphorism about "life's school of war" is never acknowledged when used by self-help authors. The idea also appears in the Nachlass: KSA 13, 1888, 15[118], p. 478, "Sprüche eines Hyperboreers": "Was uns nicht umbringt - das bringen wir um, das macht uns stärker. Il faut tuer le Wagnerisme." 
being and others' beings." (Percy 175) ${ }^{29}$ Pill 20 is extracted from the Nachlass: "Man is above all a judging animal." ${ }^{30}$ (KSA 12, 4[8], 1886: 182) This sentence of Nietzsche's appears in a long development wherein he questions the belief in the subject/predicate relationship. But in Percy's book it is used to briefly explain that "Our judgments - and preconceptions - are natural filters between reality and us" (Percy 46), which is why we have to meditate in order to stop judging ("Buddhist" meditation exercises follow Percy's comment). Nietzsche Antistress makes no attempt to use the 99 pills to make explicit the philosopher's ideas or to situate them within the context of the books they are extracted from. Consequently, moral-loaded narrations illustrate them, without any possibility for the reader to interpret them differently. Once again, they do not help to think: rather, they stipulate what to think and what to do, with most advices pivoting around the idea of endurance and of overcoming suffering in order for one to stop judging and gain personal peace.

It thus seems that psychic suffering is above all an occasion to grow. Self-help offers to assist us in overcoming this suffering, and to wait patiently until it ends. It thereby assumes that we are the only ones responsible for this suffering, which is why we should stop whining about it. Illouz writes accurately on this topic: "The disturbing question regarding the distribution of suffering (or theodicy) — why do the innocent suffer and the wicked prosper? - that has haunted world religions and modern social utopias, has been reduced to an unprecedented banality by a discourse that regards suffering as the result of mismanaged emotions or a dysfunctional psyche or even an inevitable stage in one's emotional development." (Illouz 246) In a chapter dedicated to pain and suffering, Marinoff asserts that whereas pain, understood as physical, is a signal that something is wrong in our body and that we have to pay attention to it, suffering, as a mental state, cannot be inflicted to us "without our tacit consent." (Marinoff Therapy 143) The presupposition is that we are responsible for our feelings, and we can act upon them. In the next two pages, Marinoff writes that when basic needs (he does not specify which) are met, "suffering is all about unsatisfied wonts rather than unmet needs." The Nietzschean approach of suffering, of questioning the genealogy and value of it, is never addressed.

\footnotetext{
29 "Si la tourmente ne nous tue pas, comme le souligne Nietzsche, nous aurons acquis une expérience vitale essentielle qui nous aidera à affronter des difficultés futures et à sauver notre être et celui des autres."

30 "Der Mensch is vor Allem ein urtheilendes Thier." It seems that the sentence does not appears in published works under the same condensed form, even though the subject is extensively developed by Nietzsche. References to Nietzsche's quotes are not given in Percy's book.
} 
Allan Percy's own approach seems to be one of transforming each of the 99 aphorisms he chose into advices immediately applicable by the reader in order for her or him to feel eased. Indeed, perhaps since "Philosophy does not have negative side effects" (Percy 209), his book's back cover explains that Nietzsche "shows us the way of serenity to find... happiness!" The sentences seem to have been chosen as pills according to their ability to say something about what the reader can do to slightly operate modifications within himself or herself, in order to get rid of suffering. The common denominator of all "explanations" is the absence of any advice to trace back the source of this suffering and act upon it: once suffering is established as a primary psychic experience, the search for its possible external source is of no real importance. We are supposed to talk of suffering only when the personal weaknesses of those who feel it are evoked. Our efforts must then be directed towards the reinterpretation of suffering in order to give a meaning to it that will eventually allow us to find a space for it in our personal accounts of ourselves.

Strangely, we are then brought precisely within the context that Nietzsche evokes in Human all too human I, 1108 , where he writes that there are two possibilities as regards how one can react when assailed by an illness: one can get rid of its cause, or one can "change the effect it produces on our sensibilities," which is the way of religion, metaphysics, and of a certain kind of art. Nietzsche adds: "The more a man inclines towards reinterpretation, the less attention he will give to the cause of the illness and its removal." The preparatory fragment of this paragraph indicates that it is "the lowest level of medicine," and that religions agree on "making us loose sight of the cause of sufferings." 31 As Heidi Marie Rimke stated it, self-help books contribute to forge citizens that are "governable, predictable, calculable, classifiable, self-conscious, responsible, self-regulating and self-determined" (Rimke 63). Helf-help would have it that our only power as individuals is to operate some modifications within ourselves in order to reduce our inherent existential suffering. The idea that an oppressive environment, or tragic circumstances, could be held responsible for our suffering is in the best case neglected, and in the worse case considered as a denial of reality and of our responsibilities. We ought to bear suffering! And we ought to learn a lesson from everything that happens to us - any unexpected event and any action undertaken should be the occasion for us to progress towards a continuous adjustment. "Constructed and acted upon as such, individuals are rendered entirely responsible for their failure as well as their success, for their despair as well as their happiness. Indeed, this is the social subject of a liberal governance." (63) In other words, if we suffer, it is because we do not fit.

${ }^{31} \mathrm{KSA} 8,18[33], 1876$, p. 322. 


\section{Morals of happiness}

Self-help makes us believe that we can educate and elevate ourselves through philosophy thanks to books that guide us from one psychological state (suffering, doubt, etc.) to another (ease, tranquillity, peace of mind, etc.). The idea sold here is that we have to make a certain amount of effort to reach our goal, but not too much: the effort ought to remain moderate, and the result ought to be accessible to everyone. ${ }^{32}$ If we fail to reach happiness, it is our responsibility.

This idea of personal happiness as being the priority task of philosophy now meets strong criticisms. In France, Roger-Pol Droit, after having written extensively about daily and practical philosophy, recently wrote La philosophie ne fait pas le bonheur, et c'est tant mieux! ("Philosophy does not make one happy, and this is a good thing!"), in which he reaffirms the primary task of philosophy as critical and ethical thought. In Germany, Wilhelm Schmid also worked on the subject for a while. But we can also quote Nietzsche's own position towards the moral of happiness:

All the systems of morals which address themselves with a view to their "happiness," as it is called-what else are they but suggestions for a behaviour adapted to the degree of DANGER from themselves in which the individuals live; recipes for their passions, their good and bad propensities, insofar as such have the Will to Power and would like to play the master; small and great expediencies and elaborations, permeated with the musty odour of old family medicines and old-wife wisdom; all of them grotesque and absurd in their form - because they address themselves to 'all,' because they generalize where generalization is not authorized... (Beyond Good and Evil §198)

These "morals of happiness" also consist, he adds, in "the lowering of the emotions to an innocent mean at which level they may be satisfied."

As we have seen, Nietzsche is used in different ways to serve this purpose. As all philosophers, he is generally used as a means to find a path towards personal individual happiness. Suffering on the way is perfectly all right, as inner disorders are symptoms of our unsuitability (we could say of a wrong interpretation). But more specifically, Nietzsche is also used as an outlet. Because his writing can be violent, he allows one to accept one's violent feelings. Because he is supposed to be contradictory,

\footnotetext{
${ }^{32}$ In the best cases - for instance, when growing up is the key theme-it sometimes feels quite close to the idea of Selbstüberwindung. But even in self-help books exclusively "about" Nietzsche we rarely see any reference to this notion (a notable exception is Thomass' S'affirmer avec Nietzsche), even though the aim behind overcoming, growing, and learning is always happiness and peace of mind.
} 
one can also be contradictory. Thanks to his notions of will to power and of the Übermensch, one can also hope to dominate. Similar "arguments" "about" Nietzsche spring up in self-help literature. Mostly, since Nietzsche is individualistic, the very idea that our task as humans is to focus on ourselves seems to be reinforced both by his personal example and his philosophy. In the introduction to his Life Lessons from Nietzsche, Armstrong writes: "Nietzsche loathed all groups: he was entirely devoted to cultivating the strength and wisdom of individuals" (Armstrong 3). And Taylor Kreiss, a young self-help guru who defines himself as an "Oughtologist" (i.e. "a person developing a science of what we should do to live a Good life)" (Kreiss, About), places Nietzsche (alongside Tim Ferriss, Steve Jobs, and Tyler Durden) in the category of "Extraordinary 'fast-livers' and intellectual rock stars" (Kreiss Existential).

Because they do not even know it, but more probably because it does not serve their own purpose, these authors never evoke the fact that a great part of Nietzsche's work is devoted to analyzing the values that weaken or the ones that strengthen civilization and to studying the history of culture (see, e.g., Untimely Meditation 2). It goes without saying that the idea that Nietzsche had something to say about politics or history is far from the preoccupation of self-help authors...

Nietzsche's works teach its readers that they must be very careful not to caricaturize his thought by reducing it to some shock-phrases constructed of seductive concepts. Self-help falls through the traps we all risk to slide in while reading Nietzsche: stopping short after a first reading, or identifying ourselves with a part of his texts that flatters our ego. To make Nietzsche's philosophy efficient in daily life, time is needed, and it is crucial. As he coined it in the 1887 foreword to his Genealogy of Morals: "Certain one quality which nowadays has been best forgottenand that is why it will take some time yet for my writings to become readable - is essential in order to practice reading as an art; a quality for the exercise of which it is necessary to be a cow, and under no circumstances a modern man!-rumination."

It is clear that philosophy, through the prism of self-help, becomes merchandise like any other good. It is distorted in order to answer capitalistic demands. Those who suffer in this world seek in self-help literature a way to reassure themselves, to be happy, or to construct themselves without having the possibility to devote a lot of time to it. But how is that even possible? Philosophy talks widely about the world, art, ethics, politics, and ecology, but no philosophy can be summarized in a few chapters, advices, or exercises. As for art and science, philosophy, understood as a field and as a practice, requires patience and stamina. Nietzsche's strong formulas are in no way shaped to make his thinking easier to swallow, on the contrary. The very nature and practice of philotherapy imply a simplification of the works of philosophers. We 
could see those practices as a good sign: eventual encounter of a wide audience with strong thoughts that shaped the world. But as it is, it seems closer to "junk philosophy," which, like junk food, fulfils a sharp desire (or perhaps even need), but whose effect does not last and will probably make one sick on the long term. ${ }^{33}$

\section{Works Cited}

ARMSTRONG, John. Life Lessons from Nietzsche. Macmillon, The School of Life series, 2015.

CLEMENT, Jean-Yves. Nietzsche au jour le jour: un florilège pour tous et pour personne. Paris: Le Passeur, 2013.

De Botton, Alain. The Consolations of Philosophy. New York: Penguin, 2001.

DolBY, Sandra K. Self-Help Books: Why Americans Keep Reading Them. Urbana/Chicago: University of Illinois Press, 2005.

DroIT, Roger-Pol. La philosophie ne fait pas le bonheur, et c'est tant mieux! Paris: Flammarion, 2015.

EHRENBERG, Alain. La société du malaise. Paris: Odile Jacob, 2010.

FERRISS, Tim. The 4-Hour Workweek: Escape 9-5, Live Anywhere, and Join the New Rich. New York: Crown, 2007.

-. "Stoicism 101. A Practical Guide for Entrepreneurs." Thefourhoursweek. Thefourhoursweek, n.d., Web: n. pag. Apr., 13, 2009.

—. "Philosophy as a Personal Operating System from Seneca to Musashi." Web. Thefourhoursweek.com. Thefourhoursweek. Thefourhoursweek, n.d., Web: n. pag. May, 18, 2011.

HADOT, Pierre. Exercices spirituels et philosophie antique. Paris: Albin Michel, 1981.

HOLIDAY, Ryan. The Obstacle is the Way: The Timeless Art of Turning Trials into Triumph. New York: Penguin, 2014.

HORVILLEUR, Alain. "Philothérapie”. Le garde-mots. Web. 6 March 2009.

HuME, David. An Enquiry Concerning Human Understanding. Ed. T. L. Beauchamp, Oxford: Clarendon Press, 2000.

ILlouZ, Eva. Saving the Modern Soul: Therapy, Emotions, and the Culture of Self-Help, Berkeley (CA): University of California Press, 2008.

\footnotetext{
${ }^{33}$ I wish to warmly thank the two anonymous reviewers of this paper for their most helpful comments and advices, the people who improved so strongly my English, and Martine Béland at PhøenEx for her constant support during the translation, revision, and publication process of this paper.
} 
IMBER, Jonathan B. (Ed.). Therapeutic Culture: Triumph and Defeat. New Brunswick (NJ): Transaction, 2004.

JEANMART, Gaëlle. "Allô docteur? Le docteur en philosophie ou le philosophe thérapeute," Espace de libertés, Sept. 2015, n 441: 56-59. www.philocite.eu

JefFERS, Susan. End the Struggle and Dance With Life. New York: St Martin Press 1996.

KabAt-ZinN, Jon. Wherever You Go, There You Are. NewYork: Hyperion, 1994.

Kofman, Sarah. Nietzsche et la métaphore. Paris: Payot, 1973.

KREISS, Taylor. "About: the Author \& the Goal." www.taylorkreiss.com Taylorkreiss.com, n. d. Web.

-. "Existential Meditation: Because Every Man Dies but not Every Man Truly Lives!" www.taylorkreiss.com Taylorkreiss.com, n. d. Web. , n. pag. Oct. 10, 2014.

LANGer, Susanne K. Philosophy in a New Key. A Study in the Symbolism of Reason, Rite, and Art. Cambridge (MA): Harvard University Press, 1942.

LASCH, Christopher. The True and Only Heaven: Progress and Its Critics. New York: W.W. Publishing, 1991.

LE RU, Véronique. "La valeur d'un mot d'ordre: rendre la philosophie populaire." Popularité de la philosophie. Eds. Beck and Thouard. Paris: ENS, 1995. 53-64.

LOCKE, John. An Essay on Human Understanding, Ed. P.H. Nidditch. Oxford: Oxford University Press, 1975.

MALHERBE, Michel. "Philosophie facile et philosophie abstraite au $18^{\mathrm{e}}$ siècle." Popularité de la philosophie. Eds. Beck and Thouard. Paris: ENS, 1995. 65-86.

MARQUIS, Nicolas. Du bien-être au marché du malaise: la société du développement personnel. Paris: P.U.F., 2014.

MARINOFF, Lou. Plato, not Prozac. Applying Eternal Wisdom to Everyday Problems. New York: Harper Collins, 1999.

- Therapy for the Sane: How Philosophy can Change Your Life. New York: Bloomsbury, 2003 (first published as The Big Questions: How Philosophy Can Change Your Life).

NeHAMAS, Alexander. Nietzsche: Life as Literature. Cambridge/London: Harvard University Press, 1985.

PERCY, Allan. Nietzsche antistress: en 99 pilules philosophiques. Trans. By G. Pina, Paris: éd. de l'Opportun, 2011.

RIMKE, Heidi Marie. "Governing Citizens Through Self-Help Literature." Cultural Studies 14-1 (2000): 61-78. 
SCHMID, Wilhelm. Glück: Alles, was Sie darüber wissen müssen, und warum es nicht das Wichtigste im Leben ist. Frankfurt a. M./Leipzig: Insel, 2007.

SINETAR, Marsha. Do What You Love, the Money Will Follow. New York: Dell, 1987.

THOMASS, Balthasar. S'affirmer avec Nietzsche. Paris: Eyrolles, 2010

Wotling, Patrick. Nietzsche et le problème de la civilisation. Paris: P.U.F., 1995.

\section{Titles from the "Vivre en Philosophie" Series (Paris: Eyrolles)}

ALlOUCHE, Frédéric. Être libre avec Sartre, 2012.

—. Grandir avec Pascal, 2014.

BELLOQ, Céline. Être soi avec Heidegger, 2009.

-. Lâcher prise avec Schopenhauer, 2011.

Clerget-Gurnaud, Damien. Agir avec Aristote, 2012.

—. Vivre passionnément avec Kierkegaard, 2015.

GAILlON-JACQUEL, Angélique. Cueillir l'instant avec les épicuriens, 2014.

RouX, Matthias. S'estimer soi-même avec Descartes, 2016.

THOMASS, Balthasar. Etre heureux avec Spinoza, 2009.

—. S'affirmer avec Nietzsche, 2010.

\section{Works of Friedrich NIETZSCHE}

-. Kritischen Studienausgabe in 15 Bänden. (KSA) Eds. G. Colli and M. Montinari. Berlin: DTV, 1967-77.

—. Beyond Good and Evil, trans. H. Zimmern. New York: 1906, reprinted in Courier Dover Publications, 1997.

-. Human, all too Human, trans. R.J. Hollingdale. Cambridge: Cambridge University Press, 1986.

-. The Genealogy of Morals, trans. H. Barnett, Mineola/New York, DoverThrift Editions, 2003. 